\title{
First biogeographical survey of Artemia in Tanzania
}

Mlingi, Frank Thomas; Lamtane, Hieromin Amon; Chenyambuga, Sebastian Wilson; Lund, Ivar

Published in:

Journal of Applied Aquaculture

Link to article, DOI:

10.1080/10454438.2019.1660753

Publication date:

2020

Document Version

Peer reviewed version

Link back to DTU Orbit

Citation $(A P A)$ :

Mlingi, F. T., Lamtane, H. A., Chenyambuga, S. W., \& Lund, I. (2020). First biogeographical survey of Artemia in Tanzania. Journal of Applied Aquaculture, 32(3), 278-290. https://doi.org/10.1080/10454438.2019.1660753

\section{General rights}

Copyright and moral rights for the publications made accessible in the public portal are retained by the authors and/or other copyright owners and it is a condition of accessing publications that users recognise and abide by the legal requirements associated with these rights.

- Users may download and print one copy of any publication from the public portal for the purpose of private study or research.

- You may not further distribute the material or use it for any profit-making activity or commercial gain

- You may freely distribute the URL identifying the publication in the public portal

If you believe that this document breaches copyright please contact us providing details, and we will remove access to the work immediately and investigate your claim. 
Title: "First biogeographical survey of Artemia in Tanzania"

\section{Authors and their affiliations:}

1. Frank Thomas Mlingi (Corresponding author)

Sokoine University of Agriculture (SUA), Department of Animal, Aquaculture and Range Sciences (DAARS)

frankmlingi@sua.ac.tz

\section{Hieromin Amon Lamtane}

Sokoine University of Agriculture (SUA), Department of Animal, Aquaculture and Range Sciences (DAARS)

\section{Sebastian Wilson Chenyambuga}

Sokoine University of Agriculture (SUA), Department of Animal, Aquaculture and Range Sciences (DAARS)

\section{Ivar Lund}

Technical University of Denmark, Institute of Aquatic Resources (DTU Aqua) 


\begin{abstract}
In an Artemia survey conducted along the coast of Tanzania between March and July 2017, 32 salt pans in Tanga, Dar es salaam, Pwani, Lindi, and Mtwara were assessed. Of all visited salt pans, $16(50 \%)$ had either Artemia biomass or cysts or both. Body length ranged from $4.0 \mathrm{~mm}$ to $9.5 \mathrm{~mm}$, while the mean and modal lengths were $6.2 \mathrm{~mm}$ and $6.0 \mathrm{~mm}$, respectively. Temperature ranged from $27.2{ }^{\circ} \mathrm{C}$ to $48.7{ }^{\circ} \mathrm{C}$, salinity from $20 \mathrm{~g} \mathrm{~L}^{-1}$ to $>140 \mathrm{~g} \mathrm{~L}^{-1}, \mathrm{pH}$ from 5.8 to 7.8 , dissolved oxygen (DO) from $3.1 \mathrm{mg} \mathrm{L}^{-1}$ to $4.9 \mathrm{mg} \mathrm{L}^{-1}$, water depth from $10 \mathrm{~cm}$ to $75 \mathrm{~cm}$ and conductivity from $42.0 \mathrm{~ms} \mathrm{~cm}^{-1}$ to $176.6 \mathrm{~ms} \mathrm{~cm}^{-1}$. A bisexual population of Artemia franciscana is suggested. Observed cyst states included concave, biconcave, spherical and cracking cysts. This is the first to report on the occurrence of Artemia in Tanzania.
\end{abstract}

Key words: Artemia, biomass, cysts, individuals, salt pans 


\section{Introduction}

Africa contributes $2.75 \%$ of the global salt production, with most of her techniques being conventional to primitive. Tanzania produces sea, inland lake and subsoil brine salts and the operations involve more than 6000 small and artisanal producers and less than a dozen medium-to-large producers (Assey et al., 2017; Mannar and Yusufali, 2013).

Finfish fingerling production in Sub-Saharan Africa especially African catfish (Clarias gariepinus) still faces underdevelopment due to the costs of formulated feeds and imported live foods such as Artemia. This results in low quantity and quality fingerlings for stocking grow out structures (Enyidi and Mgbenka, 2015). Inland aquaculture in Tanzania has shown an increase in the annual productions of tilapia species and African catfish (Clarias gariepinus) when combined, from 952 tonnes in 2010 to 3118 tonnes in 2015 (Rukanda, 2016). This fast growth opens opportunities for investing in hatchery production due to the increased demand of fingerlings (Mwaijande and Lugendo, 2015). Until 2015, 10 private and five public hatcheries were established for production of tilapia species, African catfish (Clarias gariepinus) and marine fish. The use of Artemia in some of these hatcheries has shown improvements in survival of African catfish (Clarias gariepinus) during the early life stages, which ensures availability of fry and fingerlings for stocking grow out ponds (Rukanda, 2016). Most of the currently operating hatcheries rely on imported Artemia cysts which are rather expensive. The cysts come partly from Kenya and mostly from Asia. Despite being expensive, the quality of the cysts is hardly guaranteed. Ornamental fish dealers in Tanzania are also using imported decapsulated Artemia cysts despite being uncertain of the quality. Many small-scale ornamental fish dealers cannot afford the costs of imported Artemia; therefore, they depend on the use of organically treated waters to grow their fish. Organic treatment of water such as using animal manures to grow zooplankton, does not ensure high nutritional quality and safety for the cultured fish, while the use of Artemia with either good or poor hatching guarantees higher production and safety (Lim et al., 2002).

To supply for the increased demand of Artemia due to increased aqua-hatchery operations, exploration for new sources has been a priority, an effort that has led to improved product quantity in the market. Despite this success, the demand of cysts has increased tremendously, and aqua-hatcheries are on the lead demanding higher quantities. Future estimates of Artemia rely on availability of information about their habitat ecologies (Lavens and Sorgeloos, 2000). To obtain information on habitat ecologies, it is of paramount importance to first survey and document biogeography of Artemia. Surveys and reviews on 
Artemia distributions in different regions have depicted important alerts towards the future of Artemia production which must be ensured for aquaculture and salt production (Ben Naceur et al., 2009; Lavens and Sorgeloos, 2000; Mechaly et al., 2013; Vanhaecke et al., 1987). In Africa, records of Artemia exist for several regions including Algeria; Cape Verde; Egypt; Kenya; Libya; Madagascar; Mozambique; Morocco; Namibia; Niger; Senegal; South Africa and Tunisia. In these regions, Artemia franciscana; Artemia salina; and parthenogenetic Artemia populations have been reported (Ben Naceur et al., 2012; Kaiser et al., 2006). Most of these regions border the Mediterranean, this is not enough to cover the African distribution of Artemia. In East Africa, the occurrence of Artemia is mostly documented in Kenya, where it is reported that the currently available Artemia franciscana was introduced between 1984 and 1986 (Kaiser et al., 2006; Ogello et al., 2014a).

Due to the usefulness of Artemia in aquaculture and solar salt production, it is imperative to ensure its easy accessibility that will eventually reduce the cost of larviculture, result in exportation of processed Artemia in the future, in addition to ensuring good quality salt production. Although there is an increase in awareness of the importance of Artemia during the early life stages of fish in Tanzania, the need for research on its availability and application has hardly been attended and currently there is no information on its availability or distribution. This survey was therefore aimed at initiating records of Artemia in Tanzania through identifying Artemia sites by visiting salt pans along the coast of mainland Tanzania; determine the prospective size distribution; examine cyst hydration characteristics and observe the possible mode of reproduction. It is therefore a contribution to the biogeography of Artemia in Africa as it presents for the first time a record of Artemia availability in Tanzania. 


\section{Materials and Methods}

\section{Survey coverage}

The survey coverage involved sampling between March and July, 2017 in Tanga, Pwani, Dar es salaam, Lindi and Mtwara regions along the coast of mainland Tanzania (Figure 1; Figure2). On an annual basis, there are no months without rain in the coast, but these regions experience varying rainfall patterns (Kabanda, 2018). A total of 32 salt pans were visited, and 15 of all visited salt pans were in Tanga. Ownership of the salt pans vary from company to family level. No further information on ownership of salt pans was collected.

\section{Layout of the salt pans}

The visited salt pans have the same layout described by Mani et al. (2012). Water firstly enters a reservoir pond during high tide. After attaining desired salinity, the water is released into evaporation ponds. The resulting brine is released into crystallization ponds in which salt crystallizes out and then it is harvested.

\section{Collection of Artemia and environmental parameters}

On arrival at each salt pan, all ponds were surveyed for presence of Artemia biomass and cysts, then samplings were done in ponds where Artemia biomass and/or cysts were spotted. Artemia biomass was collected by using a plastic tea strainer while cysts were collected by passing a piece of cloth slightly below the water surface (Figure 3). Sampling was done in only one spot in a pond with Artemia biomass and/or cysts. For salt pans with more than one pond containing Artemia, the sampling was done in only one pond, and in more than one pond where Artemia biomass and cysts were found in different ponds. The samples were fixed in $98 \%$ ethanol in eppendorf tubes and stored on ice for transport. For all visited salt pans, geographical coordinates acquired by using a handheld navigator (GARMIN GPSMAP 62s) were recorded. Water depths were measured by using a measuring tape, while temperature, conductivity and $\mathrm{pH}$ were measured by using a water multiparameter meter (HANNA HI 98194). Salinity was measured by using a hand refractometer with a maximum of $140 \mathrm{~g} \mathrm{~L}^{-1}$, in cases where salinity exceeded this range, the readings were recorded as $>140 \mathrm{~g} \mathrm{~L}^{-1}$. The measurements were done at randomly different times of the day and different depths depending on the pond(s) in which Artemia biomass and/or cysts were found. Neither measurements of salt pan and pond sizes nor observations of the number of ponds in the salt production line were conducted. 


\section{Microscopic observation of cysts}

To establish a first step in understanding the relationship between external salinity, metabolic activity and physical state of cellular water in cysts as previously described (Drinkwater and Crowe, 1991), the shape (concave, biconcave or spherical) and cracking of cysts were examined by using a portable field microscope (Bressor, Biolux, German).

\section{Size distribution, descriptive statistics and map creation}

Individual total body length was measured using a ruler for a sample of 127 individuals which represented all visited locations. Descriptive statistics were conducted in the statistical computing environment of $\mathrm{R}$ version 3.4.0. Map was created using ArcGIS® software (Environmental Systems Research Institute (ESRI)). 


\section{Results}

\section{Geographical distribution}

In all regions with exception of Mtwara, Artemia biomass and cysts were found (Figure 4), where $16(50 \%)$ of all salt pans visited had either both Artemia biomass and Artemia cysts or only one stage (Table 1). Artemia biomass was found mainly in the evaporation ponds while Artemia cysts were found as floating brownish mats mainly in the corners of crystallization ponds.

\section{Environmental parameters}

During the survey, both sunny and rainy days were experienced. There were less rainy days during the survey in Tanga and more rains were experienced during visits in Pwani, Dar es salaam, Lindi and Mtwara. Recorded temperatures in the salt pans ranged from $27.2{ }^{\circ} \mathrm{C}$ to 48.7 ${ }^{\circ} \mathrm{C}$, salinity ranged from $20 \mathrm{~g} \mathrm{~L}^{-1}$ to $>140 \mathrm{~g} \mathrm{~L}^{-1}, \mathrm{pH}$ from 5.8 to 7.8 , dissolved oxygen (DO) from $3.1 \mathrm{mg} \mathrm{L}^{-1}$ to $4.9 \mathrm{mg} \mathrm{L}^{-1}$, depth from $10 \mathrm{~cm}$ to $75 \mathrm{~cm}$ and conductivity from $42.0 \mathrm{~ms} \mathrm{~cm}^{-}$

${ }^{1}$ to $176.6 \mathrm{~ms} \mathrm{~cm}^{-1}$ (Table 2). Cysts were found in shallow ponds though in some ponds, both Artemia biomass and cysts were found, these ponds were also shallower than those with only Artemia biomass. Salinity did not seem to separate Artemia from their cysts since Artemia biomass could also be found both in the highest and lowest salinities recorded. No Artemia biomass and cysts were found at temperatures below $35^{\circ} \mathrm{C}$.

\section{Size distribution}

Individual lengths were randomly distributed through all the visited regions. The modal class was 6.0 to $6.5 \mathrm{~mm}$ and average length was $6.2 \mathrm{~mm}$, while minimum and maximum lengths were $4.0 \mathrm{~mm}$ and $9.5 \mathrm{~mm}$, respectively (Figure 5).

\section{Sexuality}

Males with claspers for securely holding females during mating, females carrying ovisacs with oocytes and clasped swimming couples were observed. These are important indicators to identify sexuality in Artemia (Figure 6).

\section{Microscopic observation of cysts}

Under the microscope, cysts had either concave, biconcave or spherical shapes while some cysts found together with spherical cysts had cracks (Figure 7). 


\section{Discussion}

Morphometrics of cysts, nauplii and adult have been used to characterize Artemia and discriminate developmental stages and sexes (Ben Naceur et al., 2010; John et al., 2004).The size distribution reported in this study has most individuals less than the length Artemia salina which ranged from $8.0 \mathrm{~mm}$ to $12.0 \mathrm{~mm}$ (Dumitrascu, 2011). A higher mean size of $10.6 \pm 1.06$ mm was reported for a parthenogenetic Artemia population in India (John et al., 2004). Despite the reported significant effects of different salinity levels on total body length of Artemia franciscana (Mueller et al., 2016), the time span, amount of information available and organization of this survey may not provide sufficient information to suspect salinity as the cause of the observed distribution in total body length.

Two observations in this survey suggest presence of a bisexual population of Artemia in Tanzania: 1.) morphology which includes ovisacs with eggs as seen in females and claspers in males, 2.) mating behavior which in which a male clasp on a female. These explanations agree with previous descriptions of sexuality in an Artemia population, in which females are recognized by their ovisacs, males by their claspers. The mating behavior where a male clasps on a female has also been documented (Lent, 1977; Sugumar, 2010). However, the current speculation that the population is bisexual is not sufficiently supported since it is also possible for both types of reproduction to occur in coexisting species, that is; presence of males and females in sexual reproduction, but at the same time parthenogenetic stocks in which females and rare non-functional males are present (Ben Naceur et al., 2012; MacDonald and Browne, 1989; Mechaly et al., 2013).

Ovoviviparity occurs when environmental conditions are favorable whilst survival in temporarily unfavorable conditions is assured through oviparity in which the Artemia produce resistant cryptobiotic eggs commonly known as cysts (Mechaly et al., 2013). This argument may support the presence of cysts in some of the visited salt pans especially one in which the salinity was above $140 \mathrm{~g} \mathrm{~L}^{-1}$. Encountering cysts in salinities as low as $26 \mathrm{~g} \mathrm{~L}^{-1}$ was not considered unusual as raining had just started, and it was in these salinities where the spherical and cracking cysts were found. Spherical cysts indicate that hydration was taking place while the cracking cysts meant hatching was taking place and they were in the breaking stage as explained by Van Stappen (1996).

In addition to the natural distribution, Artemia are also distributed through purposeful introductions by man for improving salt production but also for production of live food to be used in aquaculture (Van Stappen, 1996). Purposeful introduction of Artemia in solar salt 
operations is exemplified by Kenya in East Africa (Ogello et al., 2014b). Following the genetic closeness revealed in their study, Ogello et al. (2014b) suggested that the Artemia in Tanga comes from Kenya through introductions by Kensalt management. Kenya and Tanzania share a coastline; therefore, it is wise to speculate that the bisexual Artemia from Tanzania is Artemia franciscana. However, such speculations need to be confirmed by an extensive Artemia characterization study in Tanzania.

Apart from salt pans, Artemia can be found in inland salt lakes and coastal lagoons where salinity levels are above $40 \mathrm{~g} \mathrm{~L}^{-1}$ (Kaiser et al., 2006; Kappas et al., 2004; Vanhaecke and Sorgeloos, 1980). Such water bodies are also found in Tanzania and they include inland saline lakes such as lakes; Natron, Manyara, Eyasi, Kitangiri, Balangida, Singidani, Balangidalelu, Basotu and Basoda. There are however knowledge gaps on chemistry and aquatic science in these lakes (Nzaro, 2000; Philip and Mosha, 2012). It is thus worthy to speculate the possibility that Artemia distribution in Tanzania is beyond the coastal salt pans.

The importance of Artemia in solar salt works is also acknowledged by owners of the surveyed salt pans. Despite being unaware of the mechanisms behind, the owners and workers acknowledged harvesting good quality salt in times with high densities of Artemia in the crystallization ponds. Some of the owners reported to routinely monitor Artemia and whenever they disappear, workers visit neighboring salt pans to collect Artemia biomass to inoculate in their own salt pans. The though simple understanding of the role of Artemia in the production of good quality salt agrees with Tackaert and Sorgeloos (1993) who reported on control of algal blooms by Artemia through feeding and provision of suitable substrates for halophilic bacteria which play a role in lowering the viscosity of water. Successful optimization of the interaction can thus result in improved salt production but requires proper biological management of the salt pans for good quality salt (Tackaert and Sorgeloos, 1993). 


\section{Conclusion and recommendations}

This is the first record on the availability and distribution of Artemia in Tanzania. It is believed that, the initiative will serve as an alert for future explorations for sustainable production of Artemia in Tanzania. Therefore, the authors recommend: further in depth investigations to unravel more about the distribution with regards to time, space and geographical positions of sites; assessing the reproductive mode with larger spatial and seasonal diversities using better techniques; studying the species composition with the help of molecular techniques and spatially diverse studies; social studies on the awareness and scientific studies on the integration of local Artemia in salt production and its aquaculture application in Tanzania.

\section{Acknowledgements}

This study was financially supported by DANIDA Fellowship Center under its Building Stronger Universities (BSU) phase 2 programme. Local governments which provided permission and fisheries officers who escorted the survey in Tanga, Pwani, Dar es salaam, Lindi and Mtwara deserve gratitude from the accomplishment of this work. 


\section{References}

Assey, V., Gorstein, J., Houston, R., Kavishe, F., Ndiaye, B., Shields, A., 2017.

Transforming the salt industry in Tanzania to remove obstacles to USI. IDD Newsletter. 2.

Ben Naceur, H., Jenhani, A.B.R., Romdhane, M.S., 2012. Review of the biogeography of Artemia Leach, 1819 (Crustacea: Anostraca) in Tunisia. Int. J. Artemia Biol. 2, 24 - 39.

Ben Naceur, H., Jenhani, A.B.R., Romdhane, M.S., 2010. Biological characterization of the new invasive brine shrimp Artemia franciscana in Tunisia: Sabkhet Halk El-Menzel. Int. J. Bioeng. Life Sci. 4, 107 - 113.

Ben Naceur, H., Jenhani, A.B.R., Romdhane, M.S., 2009. New distribution record of the brine shrimp Artemia. Check List 5, 281 - 288.

Drinkwater, L.E., Crowe, J.H., 1991. Hydration state, metabolism, and hatching of Mono Lake Artemia cysts. Biol .Bull. 180, 432 - 439.

Dumitrascu, M., 2011. Artemia salina. Balneo-Research J. 2, 119 - 122. doi:10.12680/balneo.2011.1022

Enyidi, U., Mgbenka, B.., 2015. Replacement of Fish Meal with Bambara Nut Waste Meal in the Diets of Larval African Catfish Clarias gariepinus Burchell (1822). Br. J. Appl. Sci. Technol. 5, 526 - 537. doi:10.9734/BJAST/2015/12886

John, C.J.A., Abatzopoulos, T.J., Marian, P.M., 2004. Characterization of a new parthenogenetic Artemia population from Thamaraikulam, India. J. Biol. Res. 2, 63 - 74.

Kabanda, T., 2018. Long-term rainfall trends over the Tanzania coast. Atmosphere (Basel). 9,155. doi:10.3390/atmos9040155

Kaiser, H., Gordon, A.K., Paulet, T.G., 2006. Review of the African distribution of the brine shrimp genus Artemia. Water SA 32, 597 - 604. doi:10.4314/wsa.v32i4.5284

Kappas, I., Abatzopoulos, T.J., Van Hoa, N., Sorgeloos, P., Beardmore, J.A., 2004. Genetic and reproductive differentiation of Artemia franciscana in a new environment. Mar. Biol. 146, 103 - 117. doi:10.1007/s00227-004-1420-9

Lavens, P., Sorgeloos, P., 2000. The history, present status and prospects of the availability of Artemia cysts for aquaculture. Aquaculture 181, 397 - 403. doi:10.1016/S00448486(99)00233-1

Lent, C.M., 1977. The mechanism for co-ordinating metachronal limb movements between joined male and female Artemia salina during precopulatory behaviour. J. Exp. Biol. 66, $127-140$. 
Lim, L.C., Cho, Y.L., Dhert, P., Wong, C.C., Nelis, H., Sorgeloos, P., 2002. Use of decapsulated Artemia cysts in ornamental fish culture. Aquac. Res. 33, 575 - 589. doi:10.1046/j.1365-2109.2002.00687.x

MacDonald, G.H., Browne, R.A., 1989. Population dynamics of an asexual brine shrimp Artemia population. J. Exp. Mar. Bio. Ecol. 133, 169 - 188. doi:10.1016/00220981(89)90043-9

Mani, K., Salgaonkar, B.B., Das, D., Bragança, J.M., 2012. Community solar salt production in Goa, India. Aquat. Biosyst. 8. doi:10.1186/2046-9063-8-30

Mannar, V., Yusufali, R., 2013. Salt production and trade in Africa. IDD Newsletter. 2.

Mechaly, A.S., Angeletti, S., De los Rios-Escalante, P., Cervellini, P.M., 2013. A review of the biology and ecology of Artemia persimilis Piccinelli \& Prosdocimi, 1968 (Crustacea: Anostraca) as basis for its management. Int. J. Artemia Biol. 3, 12 - 19.

Mueller, C.A., Willis, E., Burggren, W.W., 2016. Salt sensitivity of the morphometry of Artemia franciscana during development: a demonstration of 3D critical windows. J. Exp. Biol. 219, 571 - 581. doi:10.1242/jeb.125823

Mwaijande, F.A., Lugendo, P., 2015. Fish farming value chain analysis: policy implications for transformations and robust growth in Tanzania. J. Rural Community Dev. 10, 47 62.

Nzaro, M.A., 2000. Geothermal resources of Tanzania, in: World Geothermal Congress. pp. 1233 - 1238. doi:10.1016/0375-6505(70)90412-8

Ogello, E.O., Kembenya, E., Githukia, C.M., Betty, M., Munguti, J.M., 2014a. The occurrence of the brine shrimp , Artemia franciscana ( Kellog 1906 ) in Kenya and the potential economic impacts among Kenyan coastal communities. Int. J. Fish. Aquat. Stud. 2014; 1, 151-156.

Ogello, E.O., Nyonje, B.M., Stappen, G. Van, 2014b. Genetic differentiation of Artemia franciscana (Kellogg, 1906) in Kenyan coastal saltworks. Int. J. Adv. Res. 2, 1154 1164. doi:10.13140/2.1.1200.2886

One Planet Nations Online, 2017. Administrative map of Tanzania. Viewed on $30^{\text {th }}$ May 2018, http://www.nationsonline.org/oneworld/map/tanzania-administrative-map.htm.

Philip, J., Mosha, D., 2012. Salt Lakes of the African rift system: A valuable research opportunity for insight into nature's concenrtated multi-electrolyte science. Tanzania J. Sci. $38,1-13$. 
Rukanda, J.J., 2016. Evaluation of aquaculture development in Tanzania. Final Project, UNU-Fisheries Trining Programme. Viewed on $20^{\text {th }}$ September 2018, http://www.unuftp.is/static/fellows/document/janeth16aprf.pdf.

Sugumar, V., 2010. Reproduction in the brine shrimp Artemia Leach, 1819 (Branchiopoda, Anostraca) from South India: Laboratory cross fertility tests and mating behaviour. North. West. J. Zool. 6, 162 -171.

Tackaert, W., Sorgeloos, P., 1993. The use of brine shrimp Artemia in biological management of solar saltworks, in: Seventh symposium on salt. Elsevier Science Publishers, Amsterdam, pp. 617- 622.

Van Stappen, G., 1996. Introduction, biology and ecology of Artemia, in: Lavens, P., Sorgeloos, P. (Eds.), Manual on the production and use of livefood for aquaculture. FAO, Rome, p. 295.

Vanhaecke, P., Sorgeloos, P., 1980. International study on Artemia IV. The biometrics of Artemia strains from different geographical origin, in: Persoone, G., Sorgeloos, P., Roels, O., Jaspers, E. (Eds.), The brine shrimp Artemia. Ecology, culturing, use in aquaculture. 3, 393 - 405. Wetteren, Belgium: Universa Press

Vanhaecke, P., Tackaert, W., Sorgeloos, P., 1987. The bio - geography of Artemia: an updated review, in: Sorgeloos, P., Bengston, D. A., Decleir, W., Jaspers, E. (Eds.), Artemia research and its applications. Morphology, genetics, strain characterisation, toxicology. 1, 129 - 155. Wetteren, Belgium: Universa Press 


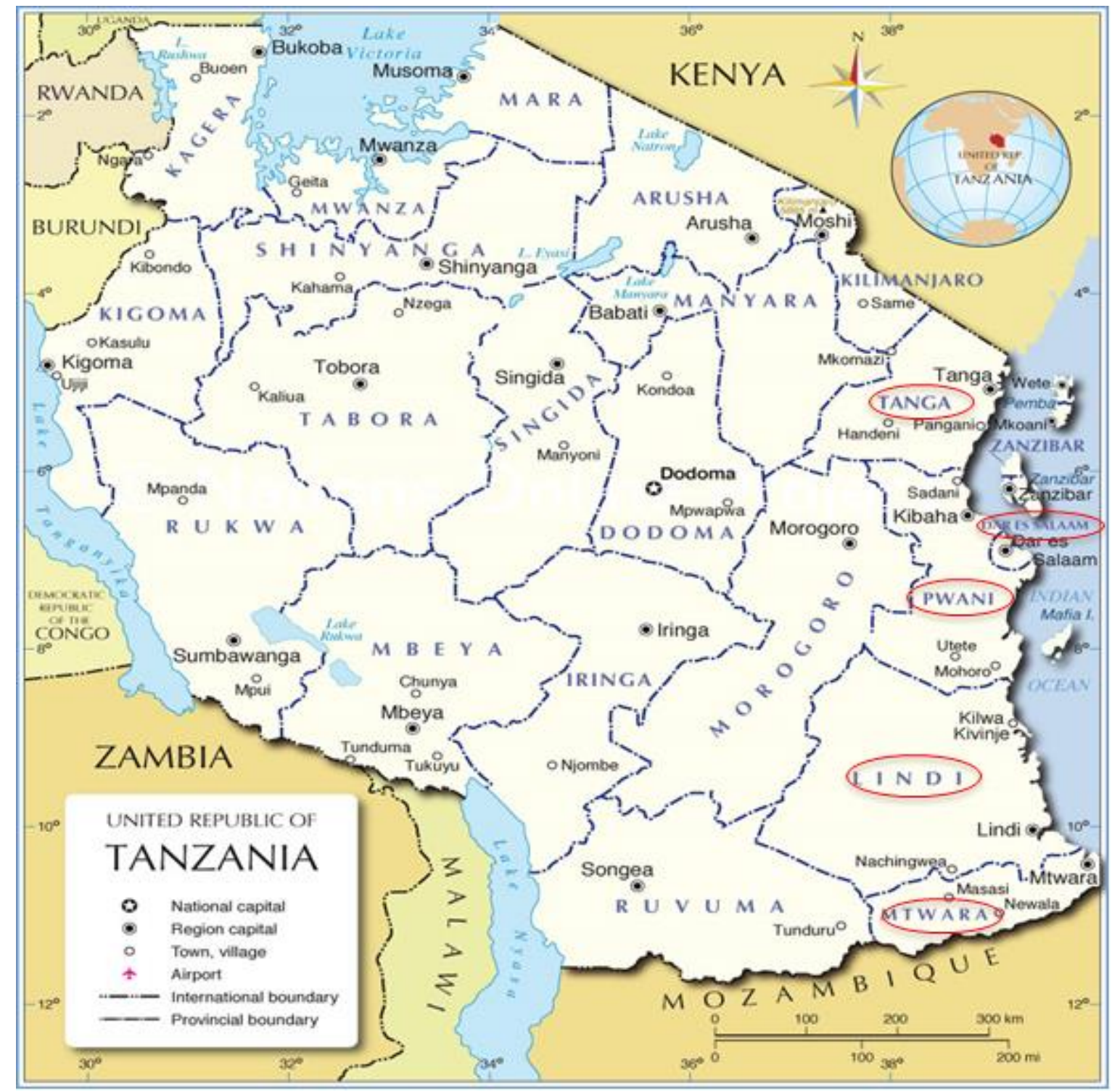

Figure 1. Map of Tanzania showing the surveyed regions (circled in red). (One Planet Nations Online 2017).

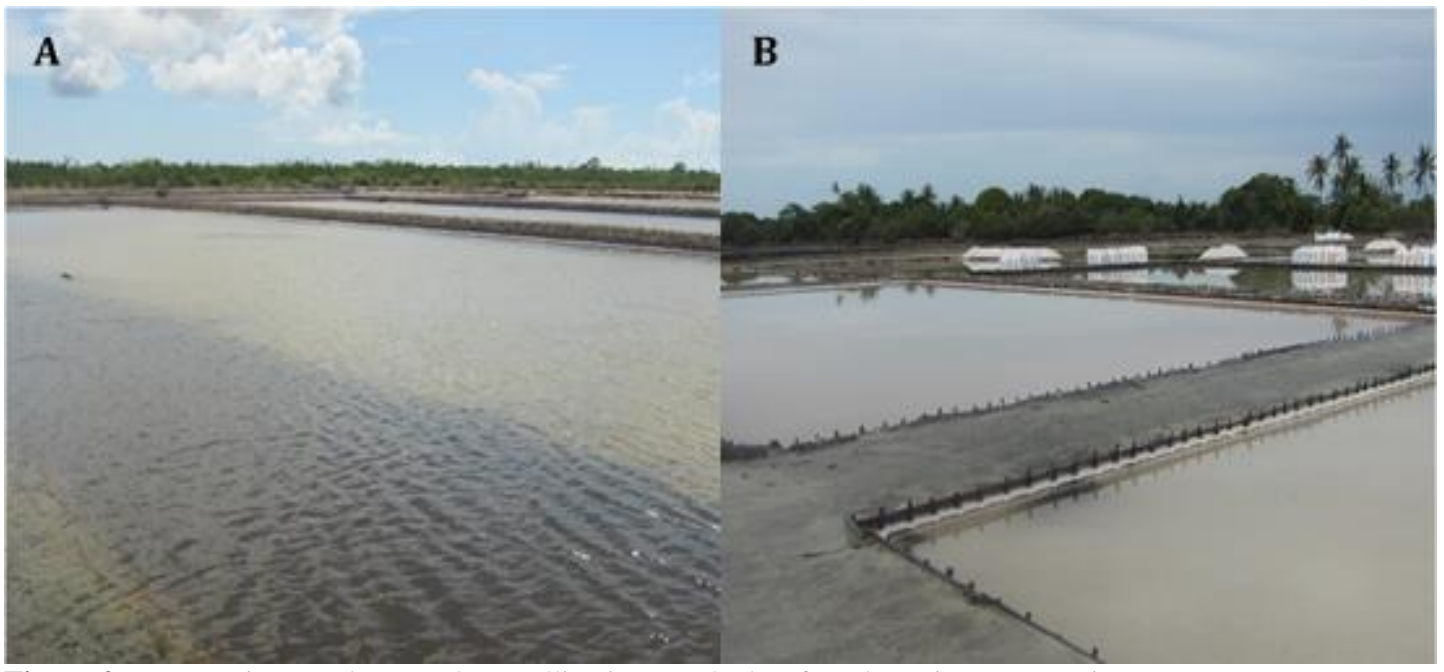

Figure 2. Evaporation ponds (a) and crystallization ponds (b) of a saltpan in Tanga region. 


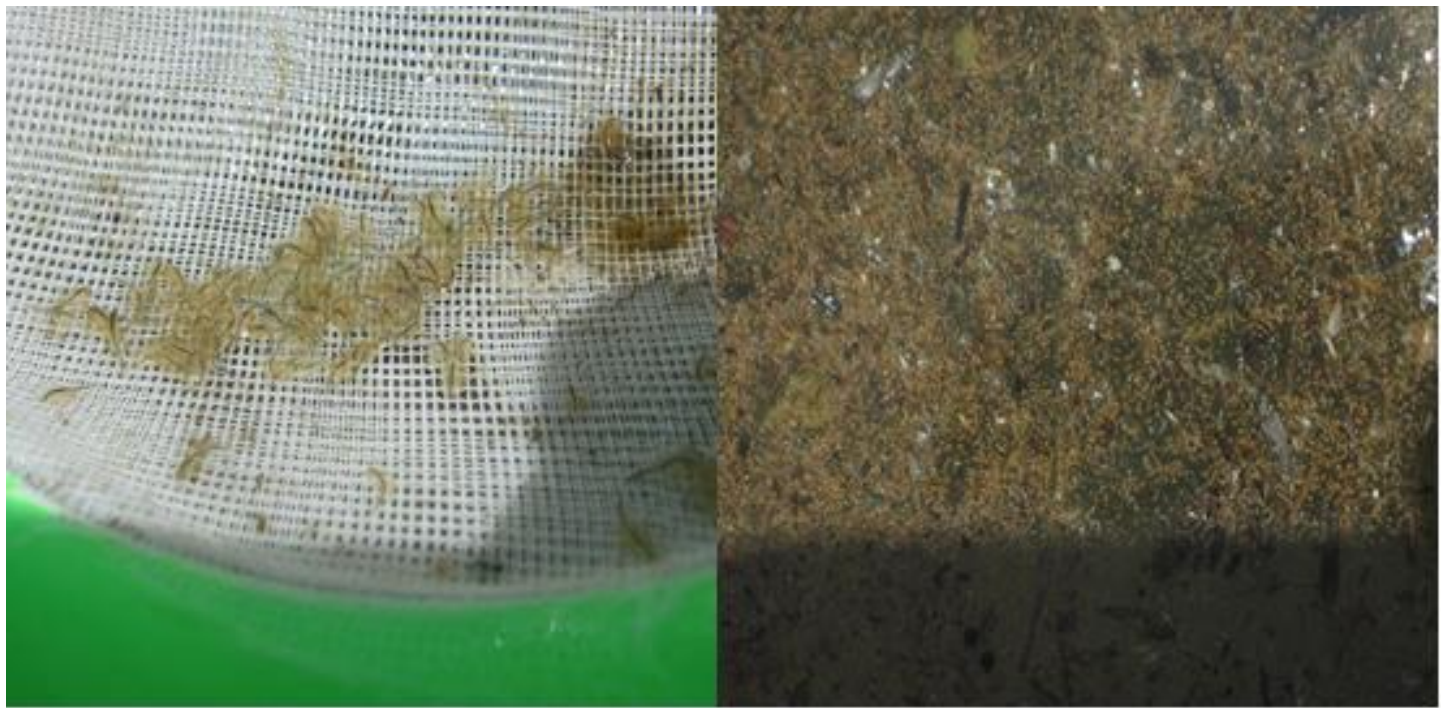

Figure 3. Artemia individuals captured in a plastic tea strainer (a) and Artemia cysts floating in a brownish mat at the corner of a crystallization pond (b).

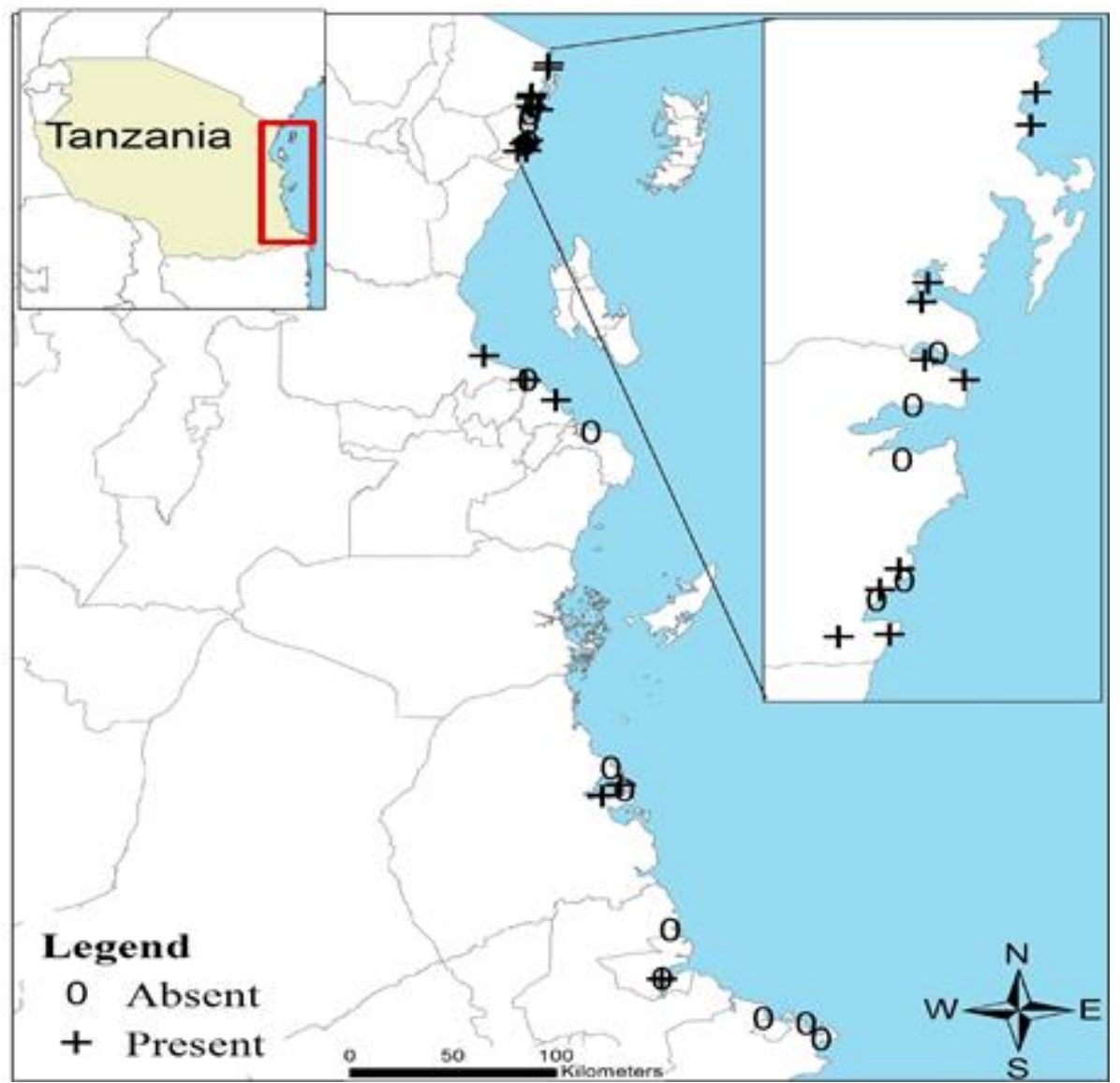

Figure 4. Geographical locations of all visited sites along the coast of mainland Tanzania. The + and 0 signs indicate the presence and absence of Artemia. A site with either Artemia biomass only or Artemia cysts only is awarded + , similar to a site with both Artemia biomass and cysts. 


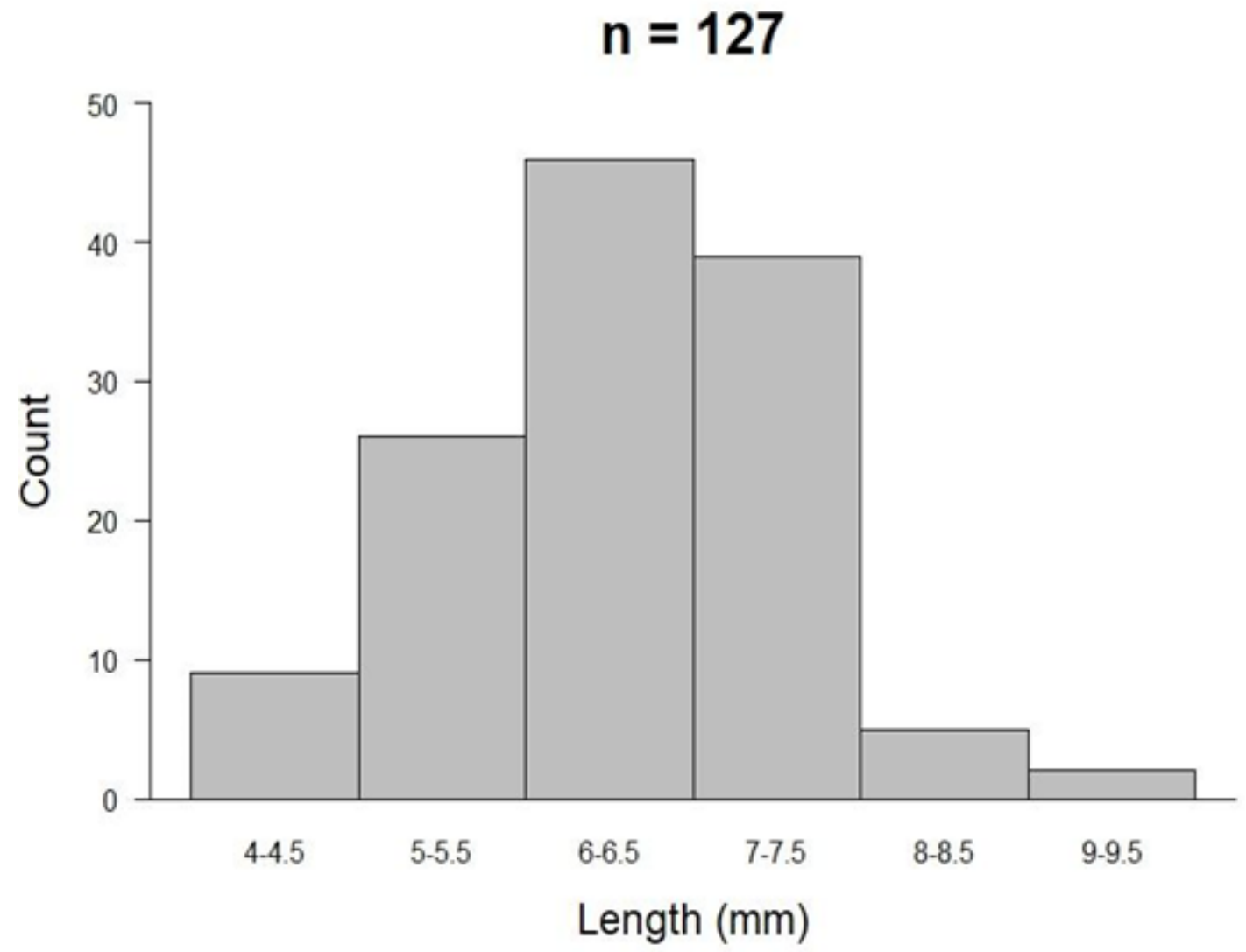

Figure 5. Frequency distribution of the total lengths of 127 Artemia individuals from random samples of all biotopes with Artemia.

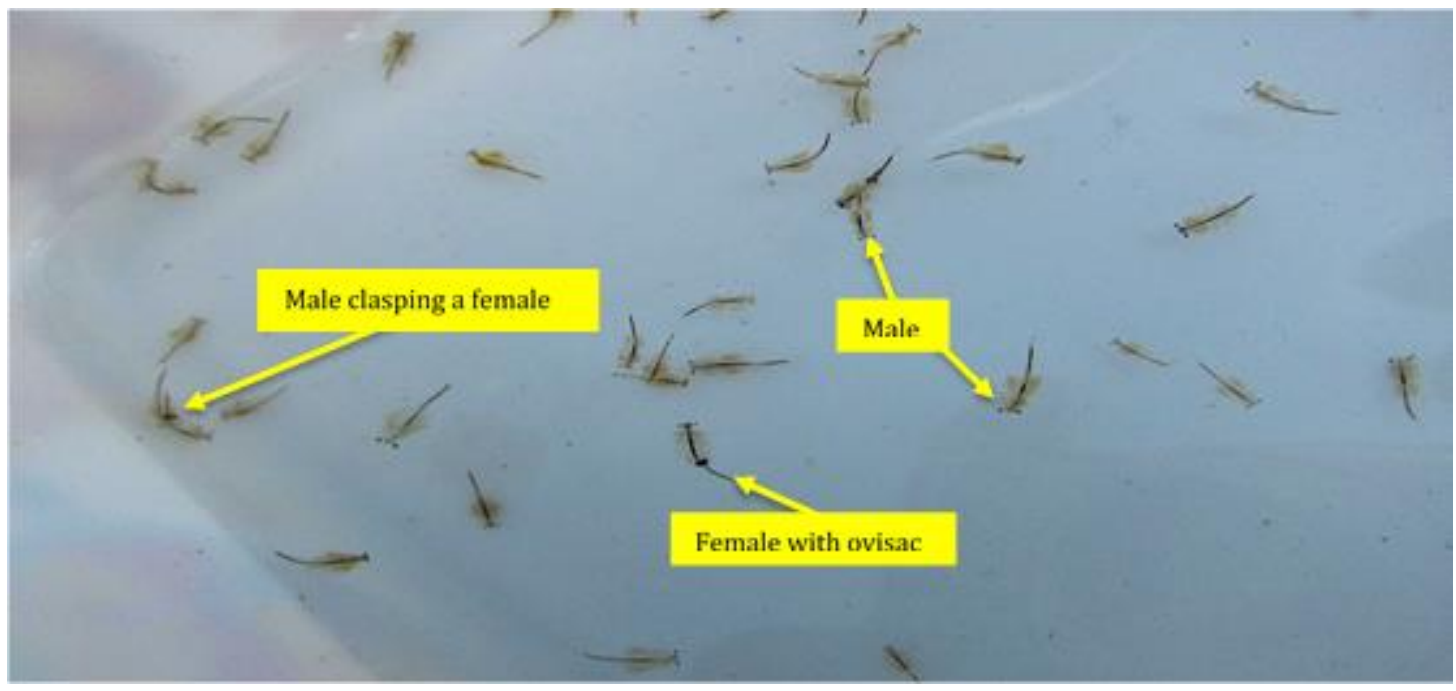

Figure 6. Artemia females, males and a mating couple as found in one of the salt pans. 


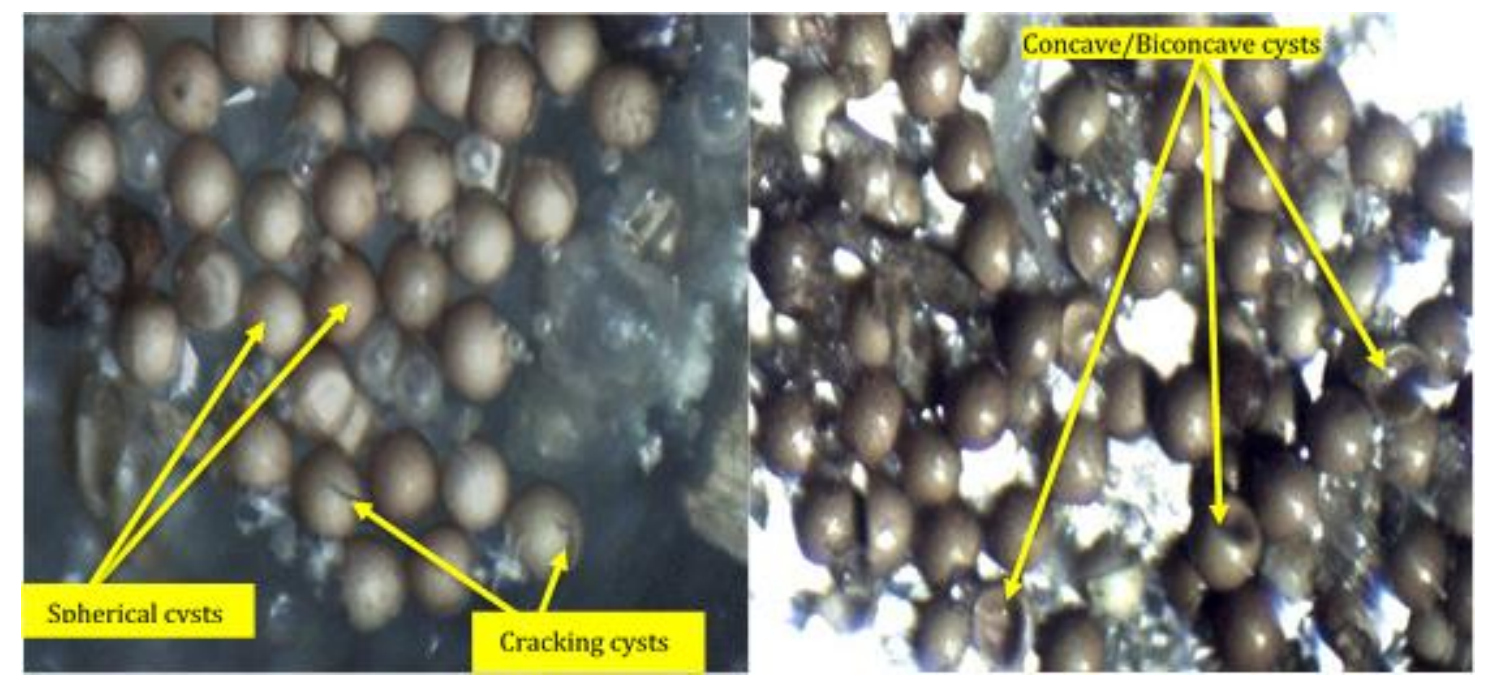

Figure 7. Microscopic view of Artemia cysts collected during the survey.

Table 1. Artemia stages in the visited salt pans

\begin{tabular}{lll}
\hline Artemia stage & Number of salt pans & Percent $(\%)$ \\
\hline Biomass only & 13 & 81 \\
Cysts only & 1 & 6 \\
Biomass and cysts & 2 & 13 \\
Total & 16 & 100 \\
\hline
\end{tabular}


Table 2. Visited biotopes along the coast of mainland Tanzania, with their characteristics observed during the survey

\begin{tabular}{|c|c|c|c|c|c|c|c|c|c|c|c|c|c|c|}
\hline \multicolumn{6}{|c|}{ Geography of biotopes } & \multicolumn{3}{|c|}{ Artemia } & \multicolumn{6}{|c|}{ Physio-Chemical Properties of Water } \\
\hline Region & S/No & Site & $\underset{(\mathbf{U T M})}{\mathbf{X}}$ & $\begin{array}{c}\mathbf{Y} \\
(\mathbf{U T M})\end{array}$ & ASL & $\mathbf{M}$ & $\mathbf{F}$ & Cysts & $\begin{array}{c}\text { Temp } \\
\left({ }^{\circ} \mathrm{C}\right)\end{array}$ & $\begin{array}{c}\text { Salinity } \\
\left(\mathrm{g} \mathrm{L} \mathrm{L}^{-1}\right)\end{array}$ & $\begin{array}{c}\text { Cond. } \\
\left(\mathrm{ms} \mathrm{cm}^{-1}\right)\end{array}$ & pH & $\begin{array}{c}\text { DO } \\
\left(\mathrm{mg} \mathrm{L} \mathbf{L}^{-}\right. \\
1)\end{array}$ & $\begin{array}{c}\text { Depth } \\
\text { (cm) }\end{array}$ \\
\hline \multirow[t]{14}{*}{ Tanga } & 1 & Mwarongo & 508851 & 9421695 & 15.02 & + & + & - & 38.5 & \multirow{2}{*}{$\begin{aligned} & 85 \\
> & 140\end{aligned}$} & 132.5 & 7.2 & 3.1 & 75 \\
\hline & 2 & Geza Ndani & 504915 & 9421431 & 15.16 & + & + & - & 47.6 & & 135.4 & 7.2 & 4.1 & 44 \\
\hline & 3 & $\begin{array}{l}\text { Saadani } \\
\text { Tongoni }\end{array}$ & 507816 & 9425223 & 15.17 & - & - & - & 42.2 & 130 & 146.6 & 7.2 & 3.7 & 10 \\
\hline & 4 & Maere & 508082 & 9426295 & 15.57 & + & + & - & 37.9 & 135 & 159.9 & 7.35 & 3.9 & 20 \\
\hline & 5 & Kivindani & 509945 & 9427214 & 12.00 & - & - & - & 36.6 & 130 & 156.0 & 6.8 & 3.2 & 20 \\
\hline & 6 & Machui & 509576 & 9428391 & 16.22 & + & + & - & 36.7 & 85 & 174.6 & 5.8 & 2.9 & 20 \\
\hline & 7 & Mwacheji & 510450 & 9445172 & 15.81 & - & - & - & 34.5 & 20 & 133.5 & 6.9 & 4.0 & 30 \\
\hline & 8 & Chongoleani & 514416 & 9447802 & 15.57 & - & - & + & 35.0 & 26 & 42.0 & 7.4 & 4.4 & 10 \\
\hline & 9 & Mpirani & 511338 & 9449805 & 15.53 & + & + & + & 40.1 & 40 & 102.5 & 7.1 & 4.6 & 20 \\
\hline & 10 & $\begin{array}{l}\text { Moa- } \\
\text { Mayomboni }\end{array}$ & 519702 & 9477295 & 16.01 & + & + & - & 38.2 & 110 & 105.9 & 7.5 & 4.9 & 60 \\
\hline & 11 & Moa & 519322 & 9473946 & 16.30 & + & + & - & 39.5 & 95 & 129.2 & 6.5 & 4.5 & 10 \\
\hline & 12 & Kibiboni & 511050 & 9455735 & 17.44 & + & + & - & 36.8 & 100 & 127.2 & 6.6 & 4.0 & 20 \\
\hline & 13 & Doda & 511508 & 9457718 & 15.19 & + & + & - & 37.2 & 95 & 112.0 & 6.8 & 4.1 & 30 \\
\hline & 14 & Kizingani & 512337 & 9450529 & 15.68 & - & - & - & 37.9 & 60 & 89.9 & 7.56 & 4.6 & 20 \\
\hline \multirow[t]{3}{*}{ Pwani } & 15 & Kingani & 509651 & 9439580 & 16.51 & - & - & - & & & & & & \\
\hline & 16 & Nunge & 488307 & 9290691 & 16.15 & + & + & - & 36.1 & 140 & 118.3 & 7.3 & 3.6 & 15 \\
\hline & 17 & Changwahela & 508386 & 9275290 & 15.80 & + & + & - & 37.7 & 140 & 130.4 & 7.0 & 4.3 & 30 \\
\hline Dar es & 18 & Ununio & 509386 & 9275290 & 15.20 & - & - & - & 48.7 & 40 & 98.9 & 7.1 & 3.2 & 30 \\
\hline \multirow{2}{*}{ Salaam } & 19 & Kunduchi & 523173 & 9262328 & 15.27 & + & + & - & 45.2 & $>140$ & 176.6 & 6.0 & 3.0 & 10 \\
\hline & 20 & Kigamboni & 540056 & 9241921 & 15.69 & - & - & - & 39.9 & 65 & 65.2 & 7.8 & 3.5 & 30 \\
\hline \multirow[t]{3}{*}{ Lindi } & 21 & Msakara & 549358 & 9027257 & 17 & - & - & - & 34.3 & 140 & 78.3 & 6.9 & 3.8 & 30 \\
\hline & 22 & Lundu & 545439 & 9009400 & 5 & + & + & - & 41.4 & 130 & 183.2 & 6.1 & 3.8 & 30 \\
\hline & 23 & Mshindo & 554118 & 9016373 & 1 & + & + & - & 39.4 & 140 & 186.2 & 6.2 & 4.0 & 30 \\
\hline
\end{tabular}




\begin{tabular}{|c|c|c|c|c|c|c|c|c|c|c|c|c|c|c|}
\hline & 24 & Mjinini & 556071 & 9013137 & 4 & - & - & - & & \multirow{4}{*}{$>140$} & \multirow[b]{3}{*}{171.1} & \multirow{4}{*}{6.6} & \multirow[b]{3}{*}{4.0} & \multirow[b]{3}{*}{15} \\
\hline & 25 & Machole 1 & 573752 & 8892347 & 18 & - & - & - & & & & & & \\
\hline & 26 & Machole 2 & 573751 & 8892190 & 1 & + & + & + & 36.7 & & & & & \\
\hline & 27 & Mchinga & 577763 & 8923529 & 22 & - & - & - & & & & & & \\
\hline \multirow[t]{4}{*}{ Mtwara } & 28 & Ufukoni & 577703 & 8923526 & -31 & - & - & - & & & & & & \\
\hline & 30 & Mitengo & 642703 & 8863533 & 2 & - & - & - & & & & & & \\
\hline & 31 & Cheleweni & 622226 & 8867057 & -4 & - & - & - & 27.2 & 53.6 & 77.2 & 7.5 & 4.7 & 27 \\
\hline & 32 & Lihanje & 649972 & 8853568 & -6 & - & - & - & 30 & 98 & 112.2 & 7.6 & 6.6 & 30 \\
\hline
\end{tabular}

Key: X (Longitude); Y (Latitude); UTM (Universal Transverse Mercator); ASL (Altitude Above Sea Level); M (Male); F (Female); Temp (Temperature); Cond. (Conductivity); DO (Dissolved oxygen) 
